\title{
B/CおよびB/C/N材料の軟X線吸収端構造と 第一原理計算を用いた電子状態の解析
}

\section{Soft X-ray absorption near-edge structures of $\mathrm{B} / \mathrm{C}$ and $\mathrm{B} / \mathrm{C} / \mathrm{N}$ materials and the analysis of their electronic state using the first-principle calculations}

\author{
石川弘通 ${ }^{a)}$, 村松康司 ${ }^{\mathrm{b})}$, 川口雅之 ${ }^{\mathrm{a}), \mathrm{c}) \text {,* }}$
}

Hiromichi Ishikawa $^{\text {a)}}$, Yasuji Muramatsu ${ }^{\text {b) }}$ and Masayuki Kawaguchi ${ }^{\text {a),c),* }}$

\begin{abstract}
Graphite-like layer materials composed of boron/carbon (B/C) and boron/carbon/nitrogen $(\mathrm{B} / \mathrm{C} / \mathrm{N})$ have been prepared by chemical vapor deposition (CVD). In order to evaluate the electronic states of these materials, the X-ray absorption nearedge structures (XANES) of the materials have been measured and analyzed by first-principle calculation using the "discrete variational (DV)-X $\alpha$ molecular orbital method". Absorption intensities of the $\mathrm{C} K$-edge XANES spectra for $\mathrm{B} / \mathrm{C}$ and $\mathrm{B} / \mathrm{C} / \mathrm{N}$ materials started to increase at energies $1.1 \mathrm{eV}$ lower than that of graphite, which suggests that the energy levels of the conduction bands of $\mathrm{B} / \mathrm{C}$ and $\mathrm{B} / \mathrm{C} / \mathrm{N}$ materials were lower than that of graphite by $1.1 \mathrm{eV}$. DV-X $\alpha$ calculation suggests that covalent bonds between boron and carbon atoms lower the bottoms of the conduction bands of these materials, compared with that of graphite. Since electron affinity is defined to be the difference between the vacuum level and the bottom of the conduction band, these results indicate that $\mathrm{B} / \mathrm{C}$ and $\mathrm{B} / \mathrm{C} / \mathrm{N}$ materials have larger electron affinities than that of graphite. Consequently, the present study supports the experimental results which have been reported for the donor-type intercalation of $\mathrm{Na}, \mathrm{Mg}$ and $\mathrm{Ca}$ into $\mathrm{B} / \mathrm{C}$ and $\mathrm{B} / \mathrm{C} / \mathrm{N}$ materials.
\end{abstract}

KEYWORDS: $B / C / N$ materials, Electronic state, XANES, Soft X-ray absorption, DV-X $\alpha$ method

\section{1. 緒 言}

グラファイトの炭素 $(\mathrm{C})$ の一部をホウ素(B)に置換したホウ 素 /炭素 $(\mathrm{B} / \mathrm{C})$ 材料，および $\mathrm{B}$ と窒素 $(\mathrm{N})$ に置換したホウ素 $/$ 炭素/窒素 $(\mathrm{B} / \mathrm{C} / \mathrm{N})$ 材料は，半金属であるグラファイトや絶縁 体の六方晶窒化ホウ素 $(h-\mathrm{BN})$ と異なり, 組成や B, C, N の網面 内の原子配置によりバンドギャップを制御できる可能性が示唆 されている ${ }^{1)}$ 。さらに, 実験的にも, 組成により電気伝導度が 変化することが報告されている2),3)。

$\mathrm{B} / \mathrm{C}$ および $\mathrm{B} / \mathrm{C} / \mathrm{N}$ 材料がアルカリ金属を化学的，あるいは電 気化学的にインターカレートすることが報告されている。例え ば筆者らを含むグループは，これらの材料がグラファイトと 同様にリチウム $(\mathrm{Li})$ を電気化学的にインターカレートすること を報告しており ${ }^{4)}$, グラファイトでは電気化学的にインターカ

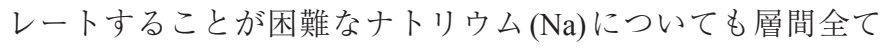
にNaが挿入された第一ステージの層間化合物の作製に成功し ている ${ }^{5), 6)}$ 。グラファイトへの Liの電気化学的インターカレー
ションは，現在の Liイオン二次電池に利用されており，B/Cお よび $\mathrm{B} / \mathrm{C} / \mathrm{N}$ 材料に対してNaを電気化学的にインターカレート できたことはNaイオン二次電池などへの応用につながる結果 である。また，グラファイトではインターカレートしにくいマ グネシウム $(\mathrm{Mg})$ について，気相法あるいは2 バルブ法と言われ る金属蒸気と反応させる方法で, $\mathrm{B} / \mathrm{C} / \mathrm{N}$ 材料にインターカレー トさせることにも成功している7)。

金属や金属イオンがインターカレートするドナー型のイン ターカレーションについてはホスト側が電子を受け取ることか ら，ホストの電子親和力とゲストのイオン化エネルギーの関係 が重要である ${ }^{8)}$ 。電子親和力は, 固体材料においては伝導帯の 底から真空準位までのエネルギー ${ }^{9)}$ とされることから，伝導帯 の底のエネルギー準位を調べることにより求められる。これま でにホスト材料として $\mathrm{B} / \mathrm{C} / \mathrm{N}$ 材料のうち $\mathrm{BC}_{2} \mathrm{~N}, \mathrm{BC}_{6} \mathrm{~N}$ の伝導带 の底のエネルギーが調べられており，グラファイトに比べて $\mathrm{BC}_{2} \mathrm{~N}$ の伝導帯の底のエネルギーが低い，すなわち電子親和力 が大きいことが示されている5)。この $\mathrm{BC}_{2} \mathrm{~N}$ は，グラファイト

* Corresponding Author, E-mail: kawaguti@osakac.ac.jp

（平成30年10月24日受理, 平成31年1月23日採択）

a) 大阪電気通信大学：干572-8530 大阪府寝屋川市初町18-8

Osaka Electro-Communication University: 18-8 Hatsu-Cho, Neyagawa, Osaka 572-8530, Japan

b) 兵庫県立大学大学院工学研究科：干671-2201 兵庫県姫路市書写2167

Graduate School of Engineering, University of Hyogo: 2167 Shosha, Himeji, Hyogo 671-2201, Japan

c) 大阪電気通信大学エレクトロニクス基礎研究所：テ572-8530 大阪府寝屋川市初町18-8

Fundamental Electronics Research Institute, Osaka Electro-Communication University: 18-8 Hatsu-cho, Neyagawa, Osaka 572-8530, Japan http://dx.doi.org/10.7209/tanso.2019.67 
にインターカレーションされにくい $\mathrm{Na}$ をインターカレートし， 伝導帯の底のエネルギーとインターカレーションの関連を示す 結果が得られている5)。

伝導帯の電子状態を調べる分光手法としては, シンクロトロ ン放射光を用いるX線吸収端構造(X-ray Absorption Near-Edge Structure, XANES) を測定する方法と，透過型電子顕微鏡を用い る電子線エネルギー損失分光法(Electron Energy Loss Spectroscopy, EELS)がある。EELSは，電子顕微鏡を使用するため高い 空間分解能をもつが, 透過型電子顕微鏡で測定するためサンプ ルを薄膜に加工することが必要となる。XANESの空間分解能 については，照射されるX線の照射範囲に依存することから， EELSには及ばないものの全電子収量 (Total Electron Yield, TEY) 法を用いればサンプルに特別な加工は必要なく容易に測定する ことができる。実際，グラファイトやh-BNの電子状態を調べ

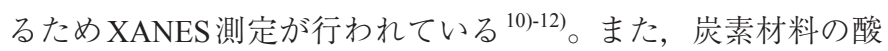
化状態についてXANESスペクトルと分子軌道計算に基づいて 解析するなど, XANESスペクトルを用いた炭素材料の分析に ついて研究が進められている ${ }^{13)-15) 。 ~}$

ヘテロ原子である $\mathrm{B} や \mathrm{~N}$ を含んだ $\mathrm{B} / \mathrm{C}$ および $\mathrm{B} / \mathrm{C} / \mathrm{N}$ 材料に おいて，材料を構成する各元素の $s p^{2}$ の反結合性軌道に相当す

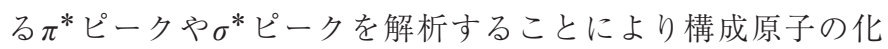

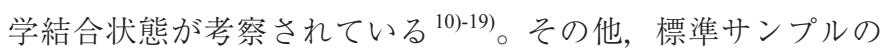
XANESスペクトルのピーク形状を指紋とし試料内に含まれる 物質の同定にも利用されている ${ }^{20)}$ 。

このように，B/Cおよび $\mathrm{B} / \mathrm{C} / \mathrm{N}$ 材料についてXANES スペク トルによる電子状態の評価および金属, 金属イオンのインター カレーションの関係については調べられてきた。しかし, B/C および $\mathrm{B} / \mathrm{C} / \mathrm{N}$ 材料の電子状態がグラファイトおよび $h-\mathrm{BN}$ と異 なる原因について詳細に調べられていない。

そこで本研究では, B/C と B/C/N 材料のXANESスペクトル 測定と第一原理計算による解析から電子状態を明らかにし, こ

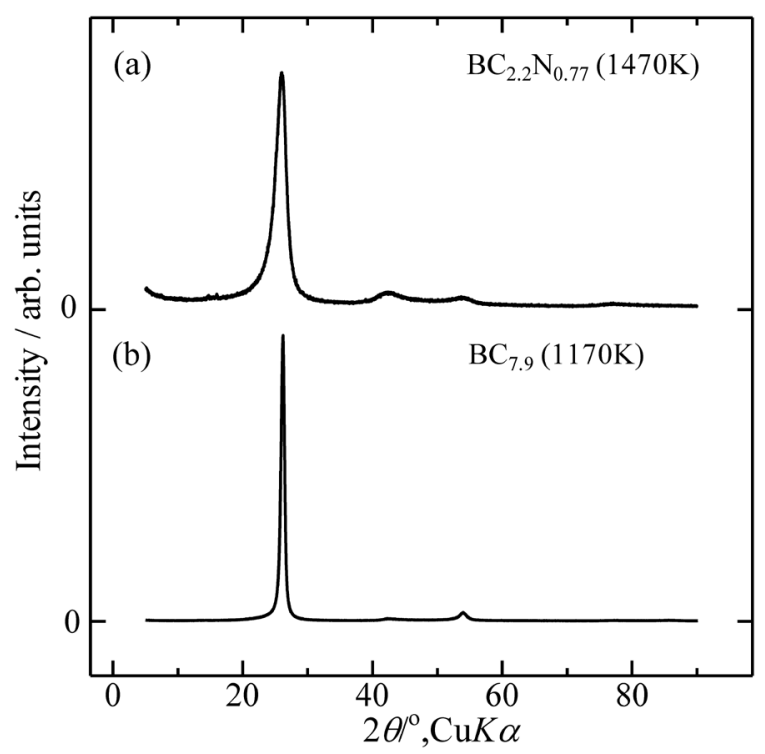

Fig. 1 XRD patterns of (a) $\mathrm{BC}_{2.2} \mathrm{~N}_{0.77}\left(1470 \mathrm{~K}\right.$ ) and (b) $\mathrm{BC}_{7.9}(1170 \mathrm{~K})$.
れらが $h$-BNとグラファイトの電子状態と異なる要因を考察し た。具体的には, $\mathrm{B} / \mathrm{C}$ および $\mathrm{B} / \mathrm{C} / \mathrm{N}$ 材料の $\mathrm{C} K$ 端 XANESについ

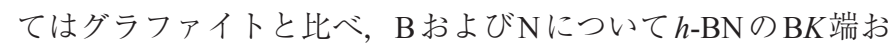
よびNK端XANES と比較し，特に伝導帯の底に注目して実験 的に調べた。さらに，B/Cおよび $\mathrm{B} / \mathrm{C} / \mathrm{N}$ 材料の分子モデルを作 成し，第一原理計算である(Discrete Variational, DV)-X $\alpha$ 分子軌 道法 ${ }^{21)}$ を用いて電子状態密度(Density of States, DOS) を算出し, 理論的な $\mathrm{B} / \mathrm{C}$ および $\mathrm{B} / \mathrm{C} / \mathrm{N}$ 材料の電子状態を調べた。 $\mathrm{DV}-\mathrm{X} \alpha$ 分 子軌道法より得られたDOS と XANESスペクトルを比較するこ とにより，各 $\mathrm{B}, \mathrm{C}$ および $\mathrm{N} の$ 化学結合が電子状態に及ぼす影 響について定性的に議論した。

以上のように，本論文ではXANESスペクトルを測定し， $\mathrm{DV}-\mathrm{X} \alpha$ 分子軌道法による解析を行うことにより， $\mathrm{B} / \mathrm{C}$ および $\mathrm{B} /$ $\mathrm{C} / \mathrm{N}$ 材料の構成原子の化学結合が材料の電子状態に及ぼしてい る影響について調べた結果を報告する。

\section{2. 実 験}

B/C/N 材料の作製については，高周波誘導加熱で 1470, 1770, あるいは $2070 \mathrm{~K} に$ 加熱したカーボンサセプターの入った反応 管に原料ガスである三塩化ホウ素 $\left(\mathrm{BCl}_{3}\right) 80 \mathrm{cc} / \mathrm{min}$ とアセトニ トリル $\left(\mathrm{CH}_{3} \mathrm{CN}\right) 40 \mathrm{cc} / \mathrm{min}$ を導入し行った。 $\mathrm{B} / \mathrm{C}$ 材料について は，原料ガスとして $\mathrm{BCl}_{3}$ を $46 \mathrm{cc} / \mathrm{min}$ およびエチレン $\left(\mathrm{C}_{2} \mathrm{H}_{4}\right)$ を $34 \mathrm{cc} / \mathrm{min}$ の流量で $1170 \mathrm{~K} に$ 加熱したカーボンサセプターの 入った反応管に導入して得た。

得られた $\mathrm{B} / \mathrm{C}$ および $\mathrm{B} / \mathrm{C} / \mathrm{N}$ 材料の組成については，Bについ ては，B/Cあるいは $\mathrm{B} / \mathrm{C} / \mathrm{N}$ 材料を白金るつぼに炭酸ナトリウム とともに入れ電気炉で $1240 \mathrm{~K}$ でアルカリ溶融し，溶融物を純 水および塩酸に溶解させた液を ICP 発光分析で質量濃度を求め た。CおよびNの組成については通常の燃焼法で質量濃度を求 めた。しかし，B/Cおよび $\mathrm{B} / \mathrm{C} / \mathrm{N}$ 材料は難燃性の材料であるこ とから，100\%から ICP発光分析で得られたBの質量濃度を差

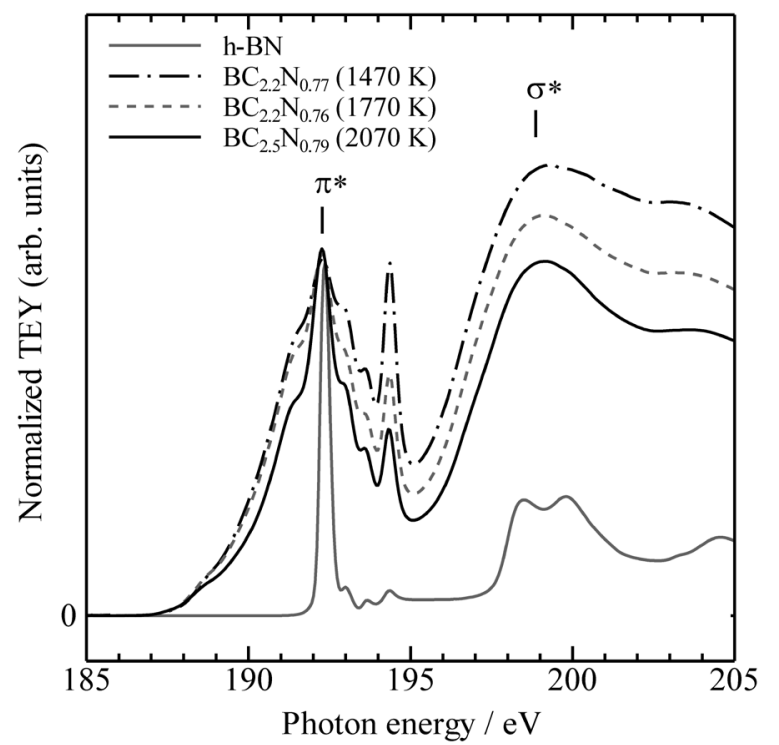

Fig. 2 BK-XANES spectra of $\mathrm{BC}_{2.2} \mathrm{~N}_{0.77}(1470 \mathrm{~K}), \mathrm{BC}_{2.2} \mathrm{~N}_{0.76}$ $(1770 \mathrm{~K}), \mathrm{BC}_{2.5} \mathrm{~N}_{0.79}(2070 \mathrm{~K})$ and $h-\mathrm{BN}$. 


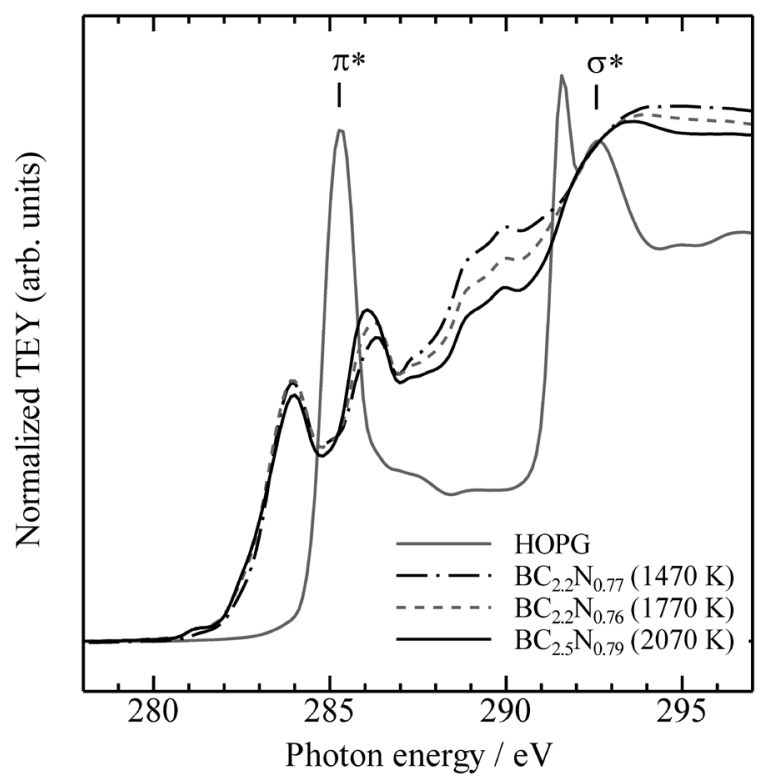

Fig. 3 C $K$-XANES spectra of $\mathrm{BC}_{2.2} \mathrm{~N}_{0.77}(1470 \mathrm{~K}), \mathrm{BC}_{2.2} \mathrm{~N}_{0.76}$ $(1770 \mathrm{~K}), \mathrm{BC}_{2.5} \mathrm{~N}_{0.79}(2070 \mathrm{~K})$ and $\mathrm{HOPG}$.

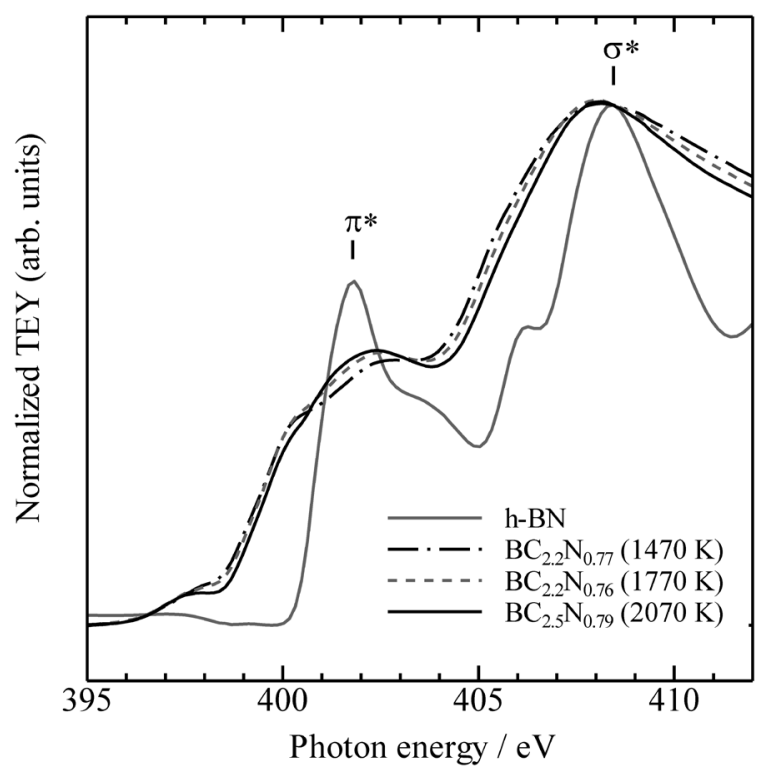

Fig. $4 \mathrm{~N} K$-XANES spectra of $\mathrm{BC}_{2.2} \mathrm{~N}_{0.77}(1470 \mathrm{~K}), \mathrm{BC}_{2.2} \mathrm{~N}_{0.76}$ $(1770 \mathrm{~K}), \mathrm{BC}_{2.5} \mathrm{~N}_{0.79}(2070 \mathrm{~K})$ and $h$-BN.

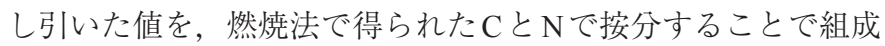
を求めた。

XANES スペクトル測定は，兵庫県立大学高度産業科学技術 研究所ニュースバル放射光施設のビームライン BL-10で測定を 行った。 $\mathrm{B} / \mathrm{C}$ および $\mathrm{B} / \mathrm{C} / \mathrm{N}$ 材料の膜試料を銅のサンプルプレー 卜上に導電性カーボンテープで保持した。膜試料に対し放射光 軟 X線を照射し，試料に流れる電流を検出する TEY法により X 線吸収スペクトルを測定した。ビームライン分光器には刻線密 度 $1800 \mathrm{~mm}^{-1}$ の回折格子を用い，BK端， $\mathrm{C} K$ 端および $\mathrm{N} K$ 端の XANES を測定した。X線の入射角は試料の配向性にXANES ス ペクトルが依存しない角度（マジックアングル）である54.5 とした ${ }^{22)}$ 。また，参照試料として $h$-BNと高配向性熱分解黒鉛 (HOPG)についてもスペクトル測定を行った。なお，B/Cおよ

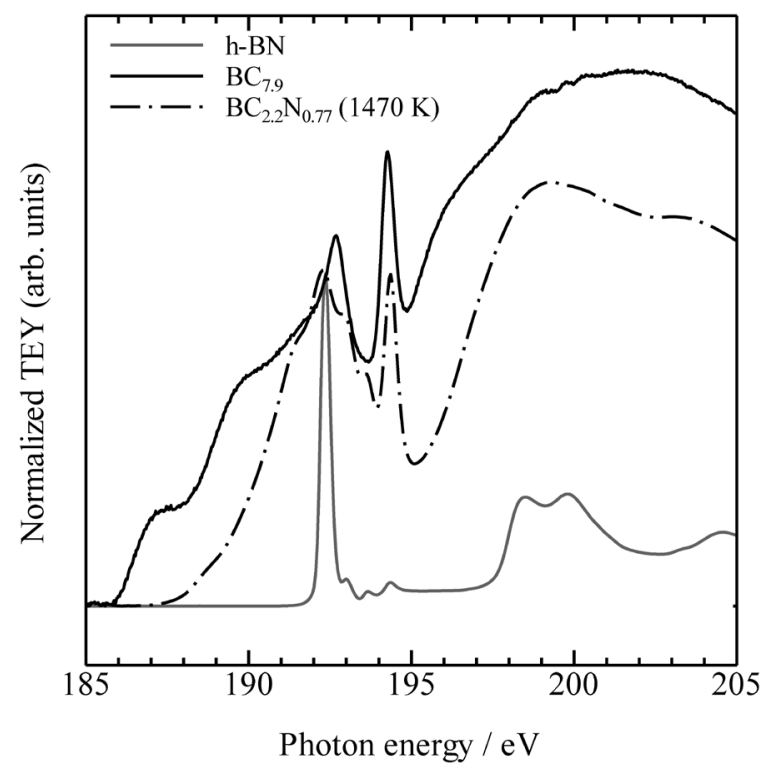

Fig. $5 \mathrm{~B} K$-XANES spectra of $\mathrm{BC}_{7.9}, \mathrm{BC}_{2.2} \mathrm{~N}_{0.77}(1470 \mathrm{~K})$ and $h$-BN.

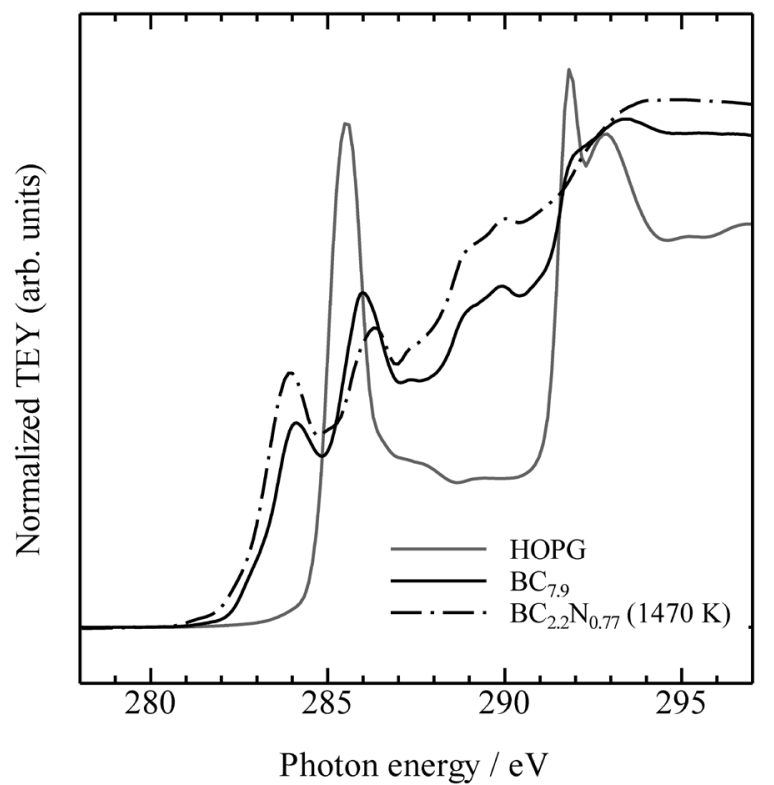

Fig. $6 \mathrm{CK}$-XANES spectra of $\mathrm{BC}_{7.9}, \mathrm{BC}_{2.2} \mathrm{~N}_{0.77}(1470 \mathrm{~K})$ and HOPG.

びB/C/N材料は空気中の酸素と反応して表面から徐々に酸化す るため, 作製後乾燥空気中で保管し 1 カ月以内に測定を行った。

XANESスペクトルの解析には，DV-X $\alpha$ 分子軌道法を用いた。 計算モデルについては，市販の分子モデリングソフトウェア Chem3D で適切なモデルを構築し MM2 法で構造最適化処理を 施して作成した。作成したモデルに対しDV-X $\alpha$ 分子軌道法を 用いて基底状態計算を行い，指定した原子の非占有 DOSを算 出した。

\section{3. 結果と考察}

\section{$3.1 \mathrm{~B} / \mathrm{C}$ と $\mathrm{B} / \mathrm{C} / \mathrm{N}$ 材料の組成および結晶構造}

$\mathrm{B} / \mathrm{C} / \mathrm{N}$ 材料の組成は, $1470 \mathrm{~K} て ゙$ 作製した場合は $\mathrm{BC}_{2.2} \mathrm{~N}_{0.77}$, $1770 \mathrm{~K}$ で作製した場合は $\mathrm{BC}_{2.2} \mathrm{~N}_{0.76}, 2070 \mathrm{~K} て ゙$ 作製した場合は 

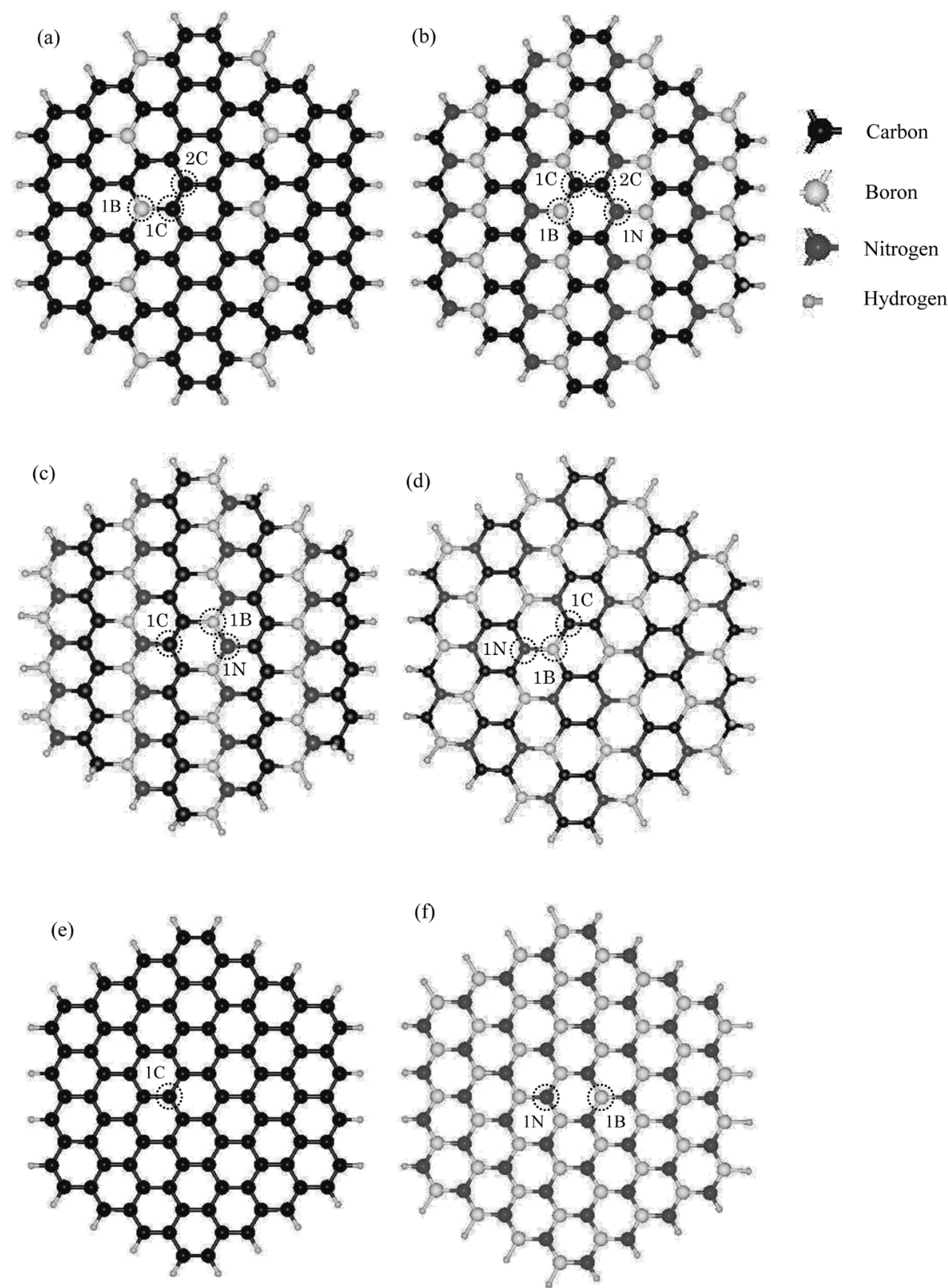

Fig. 7 (a) Model $\mathrm{B}_{10} \mathrm{C}_{86} \mathrm{H}_{24}$ as $\mathrm{BC}_{8}$. (b) Model type $1 \mathrm{~B}_{24} \mathrm{C}_{48} \mathrm{~N}_{24} \mathrm{H}_{32}$, (c) model type $2 \mathrm{~B}_{24} \mathrm{C}_{48} \mathrm{~N}_{24} \mathrm{H}_{28}$ and (d) model type $3 \mathrm{~B}_{24} \mathrm{C}_{48} \mathrm{~N}_{24} \mathrm{H}_{32}$ as $\mathrm{BC}_{2} \mathrm{~N}$. (e) Model $\mathrm{C}_{96} \mathrm{H}_{24}$ as graphite. (f) Model $\mathrm{B}_{48} \mathrm{~N}_{48} \mathrm{H}_{24}$ as $h$-BN.

$\mathrm{BC}_{2.5} \mathrm{~N}_{0.79}$ の組成になり作製温度による組成の変化はそれほど 大きくないことが確認された。以下，各 $\mathrm{B} / \mathrm{C} / \mathrm{N}$ 材料の表記は $\mathrm{BC}_{2.2} \mathrm{~N}_{0.77}(1470 \mathrm{~K})$ のように表記する。

一方， $1170 \mathrm{~K}$ で作製した $\mathrm{B} / \mathrm{C}$ 材料の組成は $\mathrm{BC}_{7.9}$ となった。 なお，今回 $\mathrm{B} / \mathrm{C}$ 材料の作製温度を $1170 \mathrm{~K}$ とたのは， $1370 \mathrm{~K}$ 以上の温度で作製すると副生成物である $\mathrm{B}_{4} \mathrm{C}$ が混入したからで ある。

Fig. 1 に $\mathrm{BC}_{2.2} \mathrm{~N}_{0.77}(1470 \mathrm{~K})$ と $\mathrm{BC}_{7.9}$ の粉末 $\mathrm{X}$ 線回折の結果を示 す。 $\mathrm{B} / \mathrm{C}$ と $\mathrm{B} / \mathrm{C} / \mathrm{N}$ 材料ともにグラファイト様層状構造を示す回 折パターンが確認できた。 $\mathrm{B} / \mathrm{C}$ 材料には, $26.14^{\circ}(d=0.341 \mathrm{~nm})$, $42.32^{\circ}(d=0.214 \mathrm{~nm})$, および $53.96^{\circ}(d=0.170 \mathrm{~nm})$ に回折線が確 認され，これらはグラファイト様層状構造あるいは乱層構造の 002 回折線，10回折線，004回折線と類似の位置に現れている。 また, B/C/N 材料は, $25.96^{\circ}(d=0.343 \mathrm{~nm}), 42.48^{\circ}(d=0.213 \mathrm{~nm})$,
および $53.96^{\circ}(d=0.170 \mathrm{~nm})$ に回折線が確認され，上記の $\mathrm{B} / \mathrm{C}$ 材料と同様の位置であった。 $\mathrm{BC}_{7.9}$ の 002 回折線の半值幅は, $\mathrm{BC}_{2.2} \mathrm{~N}_{0.77}(1470 \mathrm{~K})$ のそれより小さく, 結晶性が良好であった。 ホウ素は炭素材料に含まれると炭素材料の結晶性向上に寄与す ることが報告されており ${ }^{23)}, \mathrm{BC}_{7.9}$ の結晶性が良好なのはホウ 素の結晶性向上の効果によるものと考えられる。

\subsection{XANESスペクトル}

CK端XANESでは，選択則により炭素のC1s軌道から非占有 軌道の $\mathrm{C} 2 \mathrm{p}$ *軌道への電子遷移が反映される。 $\mathrm{C} 2 \mathrm{p}$ *軌道は伝導 帯の一番低いエネルギー準位を決めており ${ }^{24)}$, CK 端XANES の立ち上がり位置は炭素に関わる伝導帯の底となる。この伝 導帯の底から真空準位までのエネルギーが電子親和力になる

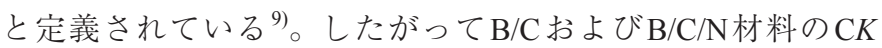
端XANESの立ち上がり位置をグラファイトと比べることによ 


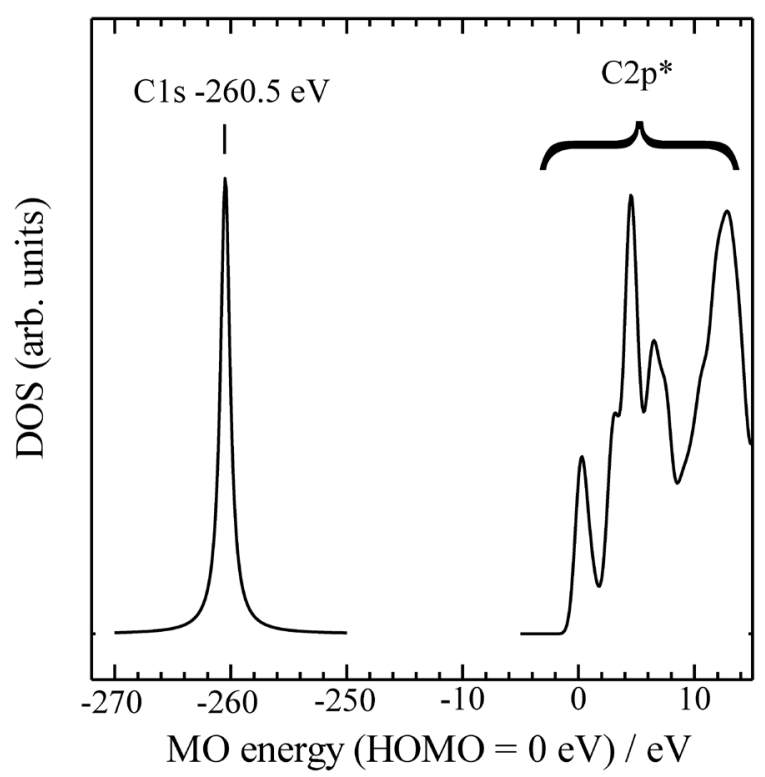

Fig. 8 The occupied $\mathrm{C} 1 \mathrm{~s}$ and unoccupied $\mathrm{C} 2 \mathrm{p}^{*}$-DOS of $1 \mathrm{C}$ atom in model $\mathrm{B}_{10} \mathrm{C}_{86} \mathrm{H}_{24}$. In this case MO energy is shown on the basis of that HOMO level is at $0 \mathrm{eV}$.

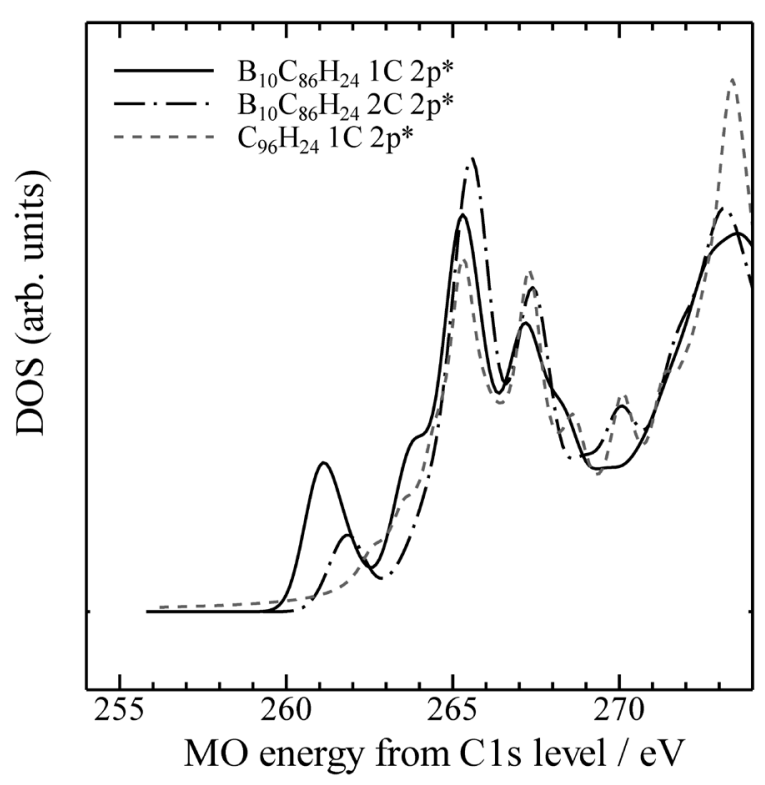

Fig. 9 The unoccupied $\mathrm{C} 2 \mathrm{p}^{*}$-DOS of $1 \mathrm{C}$ and $2 \mathrm{C}$ atoms in model $\mathrm{B}_{10} \mathrm{C}_{86} \mathrm{H}_{24}$ and $1 \mathrm{C}$ atom in $\mathrm{C}_{96} \mathrm{H}_{24}$.

り電子親和力の大きさをグラファイトと比較できる。同様に, $\mathrm{B} K$ 端と $\mathrm{N} K$ 端XANESについても参照試料の $h$-BN と電子親和 力の大きさを比較できる。

Figs. $2 \sim 4$ に $\mathrm{B} / \mathrm{C} / \mathrm{N}$ 材料の $\mathrm{B} K$ 端， $\mathrm{C} K$ 端扔よび $\mathrm{N} K$ 端XANES スペクトルを示す。BK端については $h-\mathrm{BN} の 192 \mathrm{eV} の \pi^{*}$ ピー ク， $\mathrm{N} K$ 端については $408 \mathrm{eV} の \sigma^{*} ヒ ゚ ー ク ， C K$ 端については

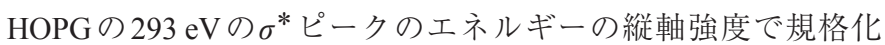
した。

Fig. 2 と Fig. 4 より，各温度で作製した $\mathrm{B} / \mathrm{C} / \mathrm{N}$ 材料の $\mathrm{B} K$ 端 と $\mathrm{N} K$ 端の立ち上がりは $h$ - $\mathrm{BN} に$ 比べ低エネルギーであり, $\mathrm{BC}_{2.2} \mathrm{~N}_{0.76}(1470 \mathrm{~K})$ で見ると $\mathrm{B} K$ 端の立ち上がりは $h$ - $\mathrm{BN}$ より $4.5 \mathrm{eV}$ (Fig. 2), NK端の立ち上がりは $3.9 \mathrm{eV}$ (Fig. 4)だけ低工ネ

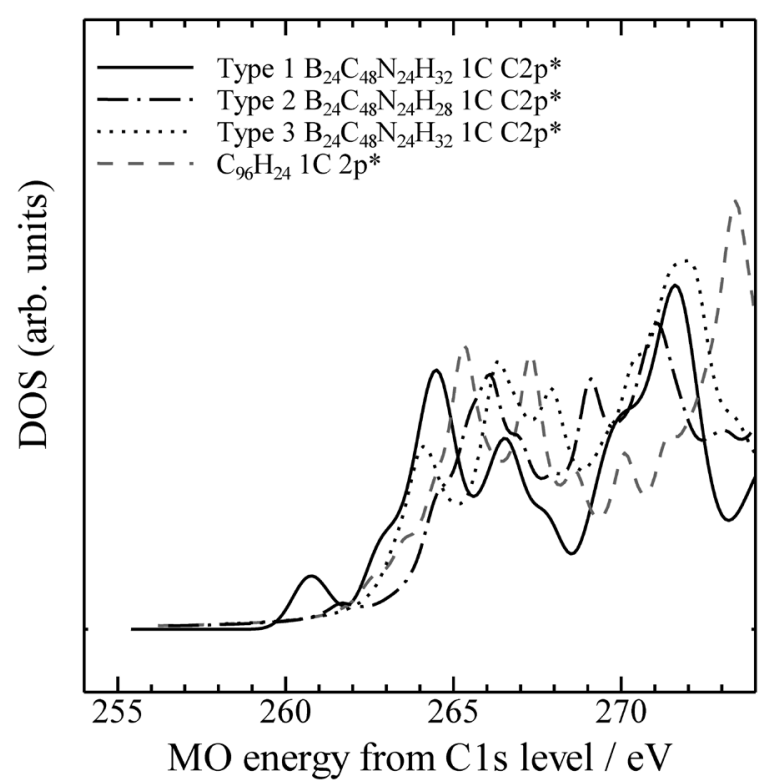

Fig. 10 The unoccupied C2p*-DOS of $1 \mathrm{C}$ atom in model type $1 \sim 3$ $\mathrm{BC}_{2} \mathrm{~N}$, and $1 \mathrm{C}$ atom in $\mathrm{C}_{96} \mathrm{H}_{24}$.

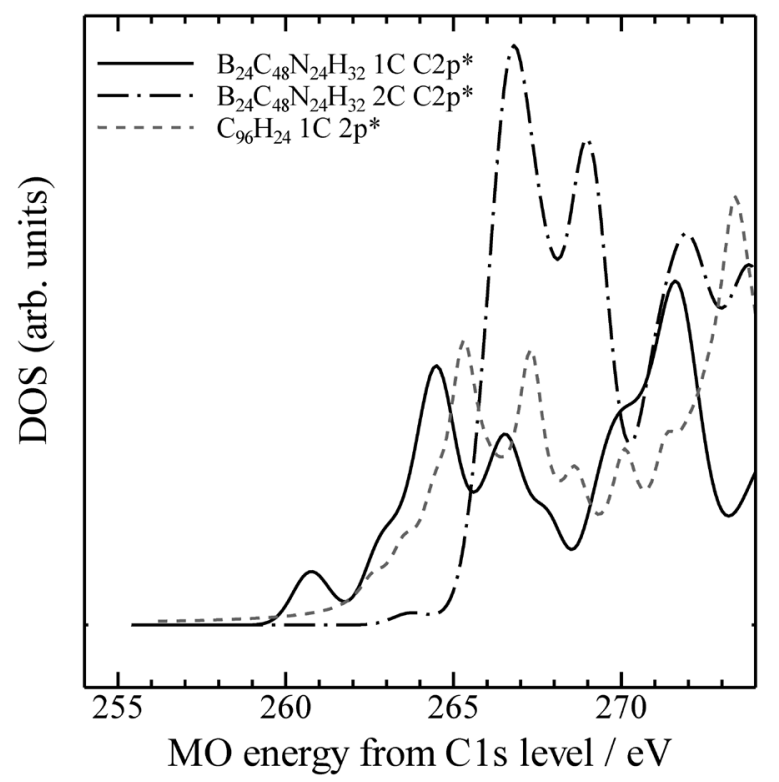

Fig. 11 The unoccupied $\mathrm{C} 2 \mathrm{p}^{*}$-DOS of $1 \mathrm{C}$ and $2 \mathrm{C}$ atoms in model type $1 \mathrm{~B}_{24} \mathrm{C}_{48} \mathrm{~N}_{24} \mathrm{H}_{32}$ and $1 \mathrm{C}$ atom in $\mathrm{C}_{96} \mathrm{H}_{24}$.

ルギー側より始まっている。一方，Fig. 3 より B/C/N 材料の $\mathrm{C} K$ 端はHOPGに比べ $1.1 \mathrm{eV}$ だけ低エネルギー側から立ち上がっ ていることがわかる。このことから， B/C/N材料の各 $\mathrm{B}, \mathrm{C}$ およ びNの伝導帯の底のエネルギー準位が $h$-BNやHOPGに比べて 低いことがわかった。特に $\mathrm{B} K$ 端や $\mathrm{N} K$ 端のエネルギー位置が $h$ - BNに比べ3.9 4.5 eV 低いのは， $h$ - BNが大きなバンドギャッ プ $(5.83 \mathrm{eV})^{25)}$ を有しており，伝導帯の底のエネルギーが高いた めと考えられる。なお， $\mathrm{B} / \mathrm{C} / \mathrm{N}$ 材料の各吸収端における立ち上 がり位置に作製温度による差は見られなかった。

Figs. 5，6にB/C および $\mathrm{B} / \mathrm{C} / \mathrm{N}$ 材料の $\mathrm{B} K$ 端と $\mathrm{C} K$ 端のXANES スペクトルを示す。 $\mathrm{B} / \mathrm{C}$ 材料は $\mathrm{B} / \mathrm{C} / \mathrm{N}$ 材料と同様に， $\mathrm{B} K$ 端と $\mathrm{C} K$ 端の吸収端の立ち上がりが $h$-BNやHOPGに比べ低エネル 


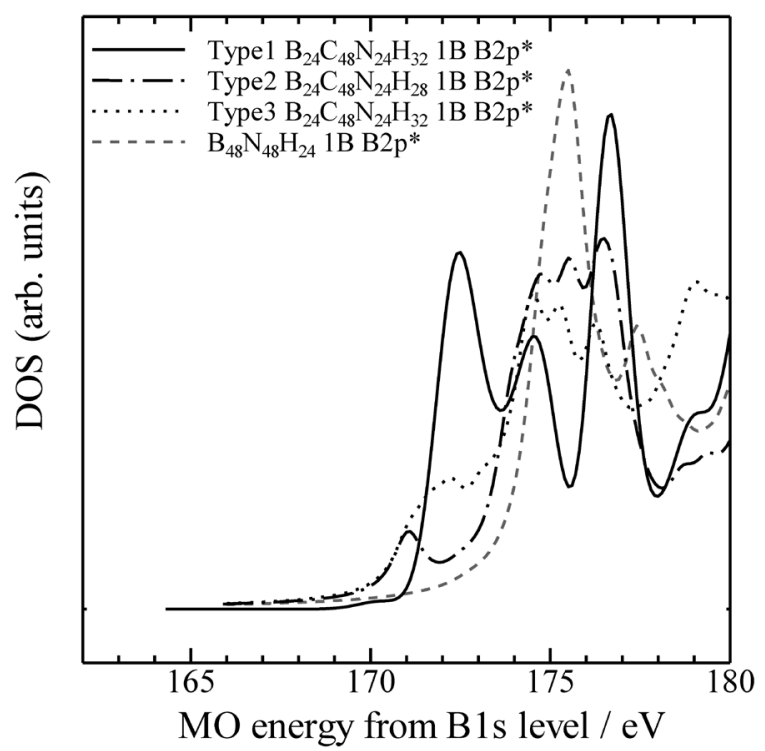

Fig. 12 The unoccupied B2p*-DOS of 1B atom in model type 1 3 $\mathrm{BC}_{2} \mathrm{~N}$ and $1 \mathrm{~B}$ atom in model $\mathrm{B}_{48} \mathrm{~N}_{48} \mathrm{H}_{24}$.

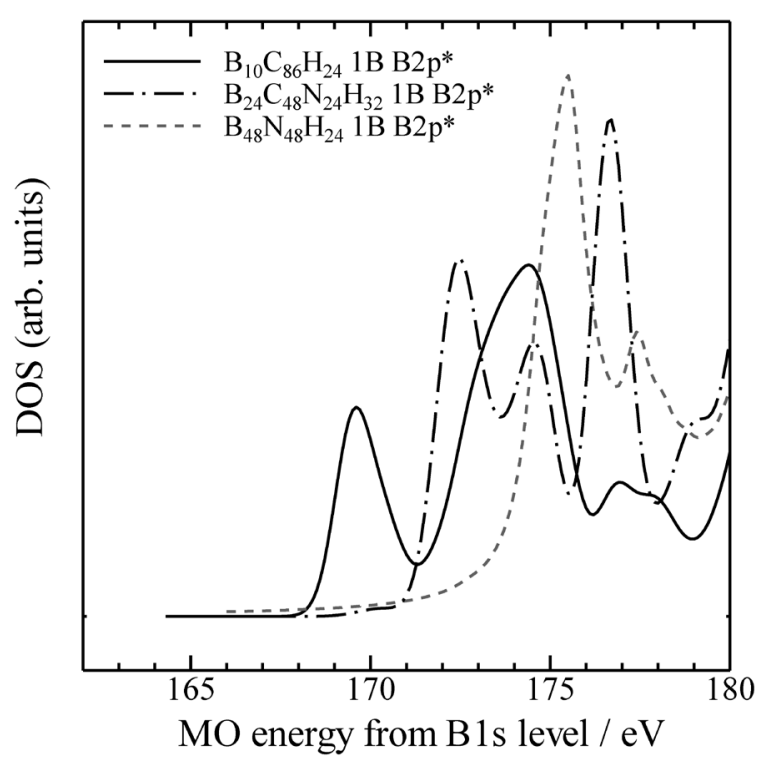

Fig. 13 The unoccupied $\mathrm{B} 2 \mathrm{p}^{*}$-DOS of $1 \mathrm{~B}$ atom in model $\mathrm{B}_{10} \mathrm{C}_{86} \mathrm{H}_{24}$, $1 \mathrm{~B}$ atom in model $\mathrm{B}_{24} \mathrm{C}_{48} \mathrm{~N}_{24} \mathrm{H}_{32}$ and $1 \mathrm{~B}$ atom in model $\mathrm{B}_{48} \mathrm{~N}_{48} \mathrm{H}_{24}$.

ギー側にあることがわかった。このことから， B/Cおよび $\mathrm{B} / \mathrm{C} / \mathrm{N}$ 材料の伝導帯の底のエネルギーはHOPGや $h$-BNに比べ低いこ とが確認できた。

ドナータイプのグラファイト層間化合物が生成する際は，グ ラファイトの電子親和力に対し，ドナーとなる金属のイオン化 エネルギーが小さい場合にインターカレーションが起こりや すいことが報告されている ${ }^{8)}$ 。今回のXANESの結果より，B/C 材料や $\mathrm{B} / \mathrm{C} / \mathrm{N}$ 材料の伝導带の底のエネルギーは, グラファイト (HOPG) $h h-\mathrm{BN}$ 上り低く, $\mathrm{B} / \mathrm{C}$ 材料や $\mathrm{B} / \mathrm{C} / \mathrm{N}$ 材料の電子親和力 がグラファイトより大きいということを示唆している。この ことは, $\mathrm{B} / \mathrm{C}$ 材料や $\mathrm{B} / \mathrm{C} / \mathrm{N}$ 材料に対しドナー型インターカレー ションが起こりやすく, $\mathrm{B} / \mathrm{C}$ 材料や $\mathrm{B} / \mathrm{C} / \mathrm{N}$ 材料が $\mathrm{Na}, \mathrm{Mg}$ 押よび Caをグラファイトに比ベインターカレートしやすい結果 ${ }^{6,7), 26)}$

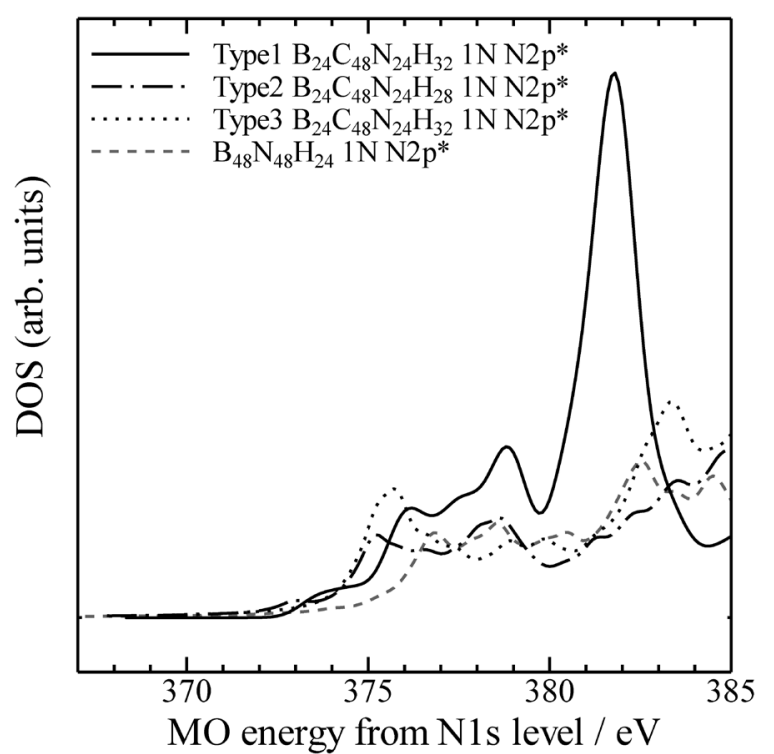

Fig. 14 The unoccupied N2p*-DOS of $1 \mathrm{~N}$ atom in model type $1 \sim 3$ $\mathrm{BC}_{2} \mathrm{~N}$ and $1 \mathrm{~N}$ atom in model $\mathrm{B}_{48} \mathrm{~N}_{48} \mathrm{H}_{24}$.

と一致している。Fig. 6に示すように，B/Cおよび $\mathrm{B} / \mathrm{C} / \mathrm{N}$ 材

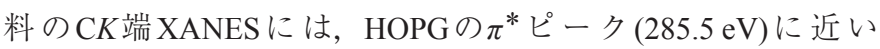
$284.0 \mathrm{eV}$ と $286.1 \mathrm{eV}$ 二つのピークが確認できる。また, B/C 材料のBK端XANES (Fig. 5)には，187.0 eVと $189.9 \mathrm{eV} に シ ョ$ ルダーピークが観察される。これらのピークについては， $\mathrm{B} / \mathrm{C}$ および $\mathrm{B} / \mathrm{C} / \mathrm{N}$ 材料中に形成される $\mathrm{B}$ と $\mathrm{C}$ 結合による $\pi^{*}$ 軌道の 分裂に起因すると考えられる。

なお， B $/ \mathrm{C} / \mathrm{N}$ 材料の $\mathrm{B} K$ 端 XANES スペクトル (Fig. 5)には酸

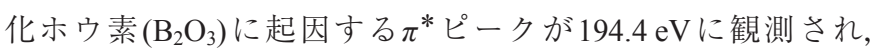
高温になるほどそのピーク強度が弱くなった。これは，高温で 作製するほど $\mathrm{B} / \mathrm{C} / \mathrm{N}$ 材料中のホウ素の反応性が低下し，表面に $\mathrm{B}_{2} \mathrm{O}_{3}$ が形成しにくくなっていることを示す。

\section{$3.3 \mathrm{DV}-\mathrm{X} \alpha$ 法によるXANES スペクトル解析}

$\mathrm{B} / \mathrm{C}$ おび $\mathrm{B} / \mathrm{C} / \mathrm{N}$ 材料のXANES $\mathrm{DV}-\mathrm{X} \alpha$ 分子軌道法で解 析するため, Fig. 7 に示すクラスターモデルを構築した。 B/C 材料のモデルとしては $\mathrm{BC}_{8}$ に対応する $\mathrm{B}_{10} \mathrm{C}_{86} \mathrm{H}_{24}$ モデルを用い た。 $\mathrm{B} / \mathrm{C} / \mathrm{N}$ 材料にはLiuが示した $\mathrm{BC}_{2} \mathrm{~N}$ 組成の3 種のモデル ${ }^{1)}$ に対応する type 1 3の三つのモデルを用いDV-X $\alpha$ 分子軌道 計算を行った。グラファイトとして $\mathrm{C}_{96} \mathrm{H}_{24}$ モデル， $h$ - $\mathrm{BN} と し$ て $\mathrm{B}_{48} \mathrm{~N}_{48} \mathrm{H}_{24}$ モデルを用いた。構築したモデルは，描画ソフト VESTA $^{27)}$ にて示した。Fig. 8 に $\mathrm{B}_{10} \mathrm{C}_{86} \mathrm{H}_{24}$ モデル(Fig. 7-a)の内 部炭素 $1 \mathrm{C}$ に対する $\mathrm{C} 1 \mathrm{~s}, \mathrm{C} 2 \mathrm{p}$ *-DOS を示す。横軸は最高被占有 軌道(HOMO)からの分子軌道(Molecular Orbitral, MO) エネル ギーで描画した。これをXANESの C1s-C2p*遷移に対応する ように，C1s 軌道からのMOエネルギーに変換したのがFig. 9 である。Fig. 9には $\mathrm{B}_{10} \mathrm{C}_{86} \mathrm{H}_{24}$ モデルにおいて $\mathrm{B}$ と結合する $1 \mathrm{C}$ とCのみと結合する $2 \mathrm{C}$ の DOSを示すとともに，グラファイト $\mathrm{C}_{96} \mathrm{H}_{24}$ モデルの内部炭素 $1 \mathrm{C} の \mathrm{DOS}$ を重ねて示す。 $\mathrm{B}_{10} \mathrm{C}_{86} \mathrm{H}_{24}$ モ デルにおいて，1Cの $2 \mathrm{p}^{*}-\mathrm{DOS}$ は $2 \mathrm{C} に$ 比べて低エネルギー側 に分布する。これは $\mathrm{B} 2 \mathrm{p}$ *軌道のエネルギー準位が $\mathrm{C} 2 \mathrm{p}$ *軌道よ り低く, B-C混成軌道の最低空軌道 $(L U M O)$ の準位が $\mathrm{C}-\mathrm{C}$ 結 
合よりも低くなるためである。次にtype 1 3の $\mathrm{BC}_{2} \mathrm{~N}$ に対応 するモデルのDOSをFig. 10 に示す。各モデルとも $\mathrm{C}_{96} \mathrm{H}_{24}$ モデ ルに比べ低エネルギー側にDOSの分布が見られた。このtype 1 3のうち最も低エネルギー側に立ち上がりをもつ type 1 の $\mathrm{B}_{24} \mathrm{C}_{48} \mathrm{~N}_{24} \mathrm{H}_{32}$ モデル (Fig. 7-b)のDOS を Fig. 11 に示す。ホウ素と 結合する炭素 $1 \mathrm{C}$ の DOS の立ち上がりが $\mathrm{C}_{96} \mathrm{H}_{24}$ モデルに比べ低 エネルギー側になっている。

これらの計算結果より，グラファイト様の六角網面構造を形 成する炭素は同じ面内でホウ素と結合することにより伝導帯の 底が下がることがわかり，XANESで観測された吸収端の低工 ネルギーシフトを説明できる。

B2p*-DOSをFigs. 12, 13 に示す。なお，横軸はB1s軌道から の $\mathrm{MO}$ エネルギーで描画した。Fig. 12 にtype $1 \sim 3$ の $\mathrm{BC}_{2} \mathrm{~N}$ に対 応するモデルの1BのDOSを示す。各モデルとも $\mathrm{B}_{48} \mathrm{~N}_{48} \mathrm{H}_{24}$ モ デルよりも低エネルギー側に状態密度の立ち上がりがある。こ のうち C $2 \mathrm{p}$ *-DOS で最も低エネルギー側に立ち上がりがあった type 1 の $\mathrm{B}_{24} \mathrm{C}_{48} \mathrm{~N}_{24} \mathrm{H}_{32}$ モデル, $\mathrm{B}_{10} \mathrm{C}_{86} \mathrm{H}_{24}$ モデル, $\mathrm{B}_{48} \mathrm{~N}_{48} \mathrm{H}_{24}$ モデ ルにおける1BのDOSをFig. 13 に示す。 $\mathrm{B}_{10} \mathrm{C}_{86} \mathrm{H}_{24}$ モデルと type 1 の $\mathrm{B}_{24} \mathrm{C}_{48} \mathrm{~N}_{24} \mathrm{H}_{32}$ モデルのDOSから, ホウ素についても炭素と同 様に，同じ面内で炭素およびホウ素と結合することにより伝導 帯の底のエネルギー準位が低くなる。しかし， $\mathrm{B}_{10} \mathrm{C}_{86} \mathrm{H}_{24}$ モデル と type 1 の $\mathrm{B}_{24} \mathrm{C}_{48} \mathrm{~N}_{24} \mathrm{H}_{32}$ モデルの状態密度の立ち上がりを比較 すると，ホウ素の伝導帯の底を下げる効果が大きいのは，ホウ 素が炭素のみと結合した場合であり，ホウ素と窒素と結合した 場合はその効果が小さくなることがわかった。これは， N2p* 軌道のエネルギー準位が $\mathrm{C} 2 \mathrm{p}$ *軌道よりも高いためである。

Fig. 14 に示す N2p*-DOSについても, type 1 3の $\mathrm{BC}_{2} \mathrm{~N}$ に 対応するモデルの方が $\mathrm{B}_{48} \mathrm{~N}_{48} \mathrm{H}_{24}$ モデルより低エネルギー側に DOSが分布し，これはFig. 4 の NK端XANES スペクトルの結果 と整合する。このことから，窒素の伝導帯の底は， B/C/N 材料 のようにホウ素および炭素と結合することにより， $h$-BNに比 べ低くなることがわかった。

以上のように, $\mathrm{B} / \mathrm{C}$ 材料や $\mathrm{B} / \mathrm{C} / \mathrm{N}$ 材料の電子状態がグラファ イトや $h$-BNの電子状態と異なるのは，これらの材料に含まれ るホウ素が大きく影響しており, 特に, ホウ素と炭素の混成軌 道が伝導帯の底のエネルギー準位を決めていることを実験的お よび理論的にも示すことができた。

\section{4. 結 論}

XANES 測定より，B/Cおよび $\mathrm{B} / \mathrm{C} / \mathrm{N}$ 材料を構成する各元素の 伝導帯の底のエネルギーがグラファイトや $h$-BNより低いこと を見いだした。DV-X $\alpha$ 分子軌道法によるXANESのスペクトル 解析より， $\mathrm{B} / \mathrm{C}$ および $\mathrm{B} / \mathrm{C} / \mathrm{N}$ 材料の伝導帯の底のエネルギーが 下がる要因は，同一網面内にあるホウ素と炭素が結合してでき る混成軌道のLUMOが低エネルギーシフトするためであるこ とがわかった。以上より，グラファイト様層状構造を有し，ホ ウ素と炭素からなる $\mathrm{B} / \mathrm{C}$ 材料がアルカリ金属や 2 族金属をイン ターカレートする有望なホスト材料になりうると考えられる。

\section{謝 辞}

本研究を行うに当たり，XANES測定を行う際にご指導いた たいた，兵庫県立大学高度産業科学技術研究所の原田哲男博士 および兵庫県立大学大学院工学研究科村松研究室の皆様に厚く 御礼申し上げる。

本研究の一部は科研費(15H03852)より補助を受けて実施した。

\section{文 献}

1) A. Y. Liu, R. M. Wentzcovitch and M. L. Cohen, Phys. Rev. B 39 (1989) 1760-1765.

2) M. O. Watanabe, S. Itoh, K. Mizushima and T. Sasaki, J. Appl. Phys. 78 (1995) 2880-2882

3) M. Kawaguchi, T. Kawashima and T. Nakajima, Chem. Mater. 8 (1996) 1197-1201.

4) M. Kawaguchi, Y. Imai and N. Kadowaki, J. Phys. Chem. Solids 67 (2006) 1084-1090.

5) M. Kawaguchi, K. Ohnishi, K. Yamada and Y. Muramatsu, J. Electrochem. Soc. 157 (2010) 13-17.

6) K. Yamada, H. Ishikawa, C. Kamiwaki and M. Kawaguchi, Electrochemistry 83 (2015) 452-458.

7) M. Kawaguchi and A. Kurasaki, Chem. Commun. 48 (2012) 6897-6899.

8) N. Bartlett and B. W. McQuillan, Intercalation Chemistry, (M. S.Whittingham and A. J. Jacobson, eds.) (1982) chap. 2, pp.19-53, Academic Press, New York.

9) E. H. Rhoderick and R. H. Williams, Matal-Semiconductor Contacts (1988) pp. 6-11, Clarendon Press, Oxford.

10) R. A. Rosenberg, P. J. Love and V. Rehn, Phys. Rev. C Nucl. Phys. 33 (1986) 4034-4037.

11) J. Moscovici, G. Loupias, P. H. Parent and G. Tourillon, J. Phys. Solids 57 (1996) 1159-1161.

12) Y. Muramatsu, T. Kaneyoshi, E. M. Gullikson and R. C. C. Perera, Spectrochim. Acta A 59 (2003) 1951-1957.

13) S. Ueda, Y. Muramatsu and E. M. Gullikson, Adv. X-Ray. Chem. Anal., Japan 38 (2007) 273-280 [in Japanese].

14) S. Ueda, Y. Muramatsu and E. M. Gullikson, Adv. X-Ray. Chem. Anal., Japan 39 (2008) 105-116 [in Japanese].

15) K. Kamamoto, Y. Muramatsu and E. M. Gullikson, Adv. X-Ray. Chem. Anal., Japan 40 (2009) 317-324 [in Japanese].

16) A. Hanafusa, Y. Muramatsu, Y. Kaburagi, A. Yoshida, Y. Hishiyama, W. Yang, J. D. Denlinger and E. M. Gullikson, J. Appl. Phys. 110 (2011) 053504 .

17) I. Caretti and I. Jiménez, J. Appl. Phys. 110 (2011) 023511.

18) R. Gago, I. Jiménez, I. Garía and J. M. Albella, Vacuum 64 (2002) 199-204.

19) I. Caretti and I. Jiménez, J. Appl. Phys. 112 (2012) 063525.

20) D. Li, G. M. Bancroft and M. E. Fleet, J. Electron. Spectrosc. 79 (1996) 71-73.

21) H. Adachi, M. Tsukada and C. Satoko, J. Phys. Soc. Jpn. 45 (1978) 875-883.

22) Y. Muramatsu and E. M. Gullikson, Adv. X-Ray. Chem. Anal., Japan $\mathbf{4 2}$ (2011) 267-272 [in Japanese].

23) C. E. Lowell, J. Am. Ceram. Soc. 50 (1967) 142-144.

24) J.-C. Charier, X. Gonze and J.-P. Michenaud, Phys. Rev. B 43 (1991) 4579-4589

25) W. Baronian, Mater. Res. Bull. 7 (1972) 119-124.

26) H. Ishikawa, H. Higuchi and M. Kawaguchi, Chem. Lett. 47 (2018) 891-893.

27) K. Momma and F. Izumi, J. Appl. Cryst. 44 (2011) 1272-1276. 